\title{
PEPERANGAN GENERASI DIGITAL NATIVES MELAWAN DIGITAL HOAX MELALUI KOMPETISI KREATIF
}

\author{
Yanti Dwi Astuti \\ yanti.astuti@uin-suka.ac.id \\ Ilmu Komunikasi UIN Sunan Kalijaga Yogyakarta
}

\begin{abstract}
The phenomenon of hoax and hate speech dissemination that occurs in the digital world has brought anxiety and concern in the community. Many of the hoax information distributed by Social Media and Instant Messaging tend to be SARA, provocative and bombastic. Ironically, not a few people who without thinking directly spread information and even reproduce the information without thinking about the impact caused after. Digital media is currently dominated by teenagers born in the millennium era and is a "digital natives" that is a generation that cannot be separated by the digital world. If this generation is not given enough ammunition to combat digital hoax, then it is feared will cause latent problems and dangers. In response to this, UIN Sunan Kalijaga Yogyakarta UI Campaign conducted an anti-hoax campaign with the target of the participants being teenagers packed through ADUIN Fest 2017 "Nyepik Becik" (Think What You Say) "on 17-18 May 2017. The approach method was participatory with Directly practicing it through the creation of creative works in the form of Print-Ad, TVC and short films by competing participants. Then held creative seminars, exhibition works, Sharing Session and Awarding Night. It is hoped that the nation's future young generation will be smart, critical and gain a good understanding so that it can combat digital hoax that can threaten the unity and unity of the nation.
\end{abstract}

\begin{abstract}
Abstrak
Fenomena penyebaran hoax dan hate speech yang terjadi di dunia digital telah membawa kecemasan dan keprihatinan di dalam masyarakat. Banyak informasi hoax, hatespeech dan cyberbullying yang disebarkan oknum melalui Social Media dan Instant Messaging yang cenderung berbau SARA, provokatif dan bombastis. Ironisnya tidak sedikit pula masyarakat yang tanpa berpikir panjang langsung menshare informasi tersebut bahkan mereproduksi ulang informasi tanpa memikirkan dampak yang ditimbulkan setelahnya. Media digital saat ini didominasi oleh remaja yang lahir di zaman millennium yang merupakan "digital natives" yaitu generasi yang tidak dapat terpisahkan oleh dunia digital. Jika generasi ini tidak diberikan amunisi yang cukup untuk memerangi digital hoax, maka dikhawatirkan akan menimbulkan masalah dan bahaya laten. Menyikapi hal ini Prodi Ilkom UIN Sunan Kalijaga Yogyakarta melakukan kampanye anti-hoax dengan target pesertanya adalah mahasiswa yang merupakan remaja akhir dan dewasa awal yang dikemas melalui kegiatan ADUIN Fest 2017 "Nyepik Becik" (Pikirkan Apa yang Kamu Katakan)" pada 17-18 Mei 2017. Metode pendekatannya dilakukan partisipatif dengan langsung mempraktekkannya melalui penciptaan karyakarya kreatif berupa Print-Ad, TVC dan film pendek oleh peserta yang dikompetisikan. Kemudian mengadakan creative seminar, pameran karya, Sharing Session dan Awarding Night. Harapannya anak-anak muda calon penerus bangsa ini menjadi cerdas, kritis
\end{abstract}


dan mendapatkan pemahaman yang baik sehingga dapat memerangi digital hoax yang dapat mengancam persatuan dan kesatuan bangsa.

Keywords: Teens, Digital Natives, Digital Hoax

\section{PENDAHULUAN}

Berdasarkan hasil survey yang dilakukan oleh APJII jumlah pengguna internet di Indonesia pada tahun 2016 sebesar $51,5 \%$ atau sebanyak 132,7 juta jiwa dari total jumlah penduduk Indonesia yaitu sebenar 252,6 juta jiwa. Pengguna internet terbanyak ada di Pulau Jawa dengan jumlah pengguna sebesar 86.339.350 pengguna atau sekitar $65 \%$ dari total pengguna di Indonesia. Pengguna internet pada umumnya didominasi jenis kelamin laki-laki yaitu sebanyak 52,5\% dan perempuan sebesar $47,5 \%$ dari total pengguna internet di Indonesia.

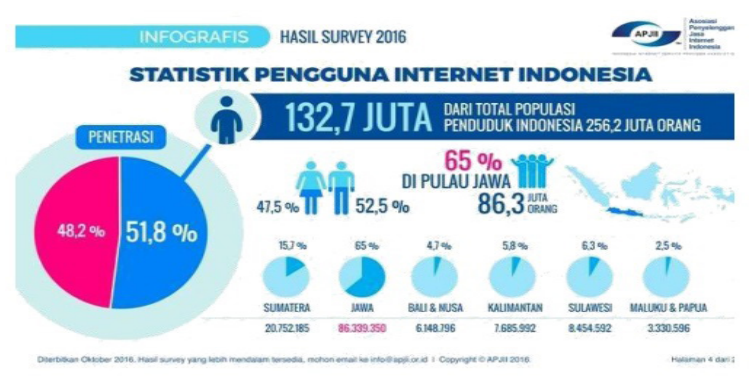

Gambar 1. Hasil Survey Warganet di Indonesia (APJII, 2016)

Teknologi Internet ibarat dua mata pedang yang berbeda, di satu sisi dapat memberikan manfaat yang positif namun disatu sisi dapat pula memberikan pengaruh yang negative manakala kita tidak dapat menggunakannya dengan baik. Sama halnya dengan berita palsu atau hoax, dibutuhkan gerakan kolaboratif guna menghantam hoax, agar tidak berimbas untuk generasi muda yang sangat akrab dengan media digital. Generasi yang lahir di era 1980-an hingga 2000-an adalah generasi yang tumbuh di era digital. Mereka ada di dunia ketika internet mulai merajalela. Marc Prensky menyebut mereka sebagai generasi digital native. Ada pula yang menyebut mereka sebagai Generasi Millineal yaitu generasi yang lahir pada rentang waktu 1982-an hingga awal 2000-an. Sedangkan generasi yang tumbuh di atas mereka, yaitu sebelum era 1982-an adalah kelompok digital immigrant, beralih dari teknologi analog terjun ke teknologi digital agar bisa berbaur dan tidak dicap sebagai orang yang ketinggalan jaman. Hasil survey APJII selanjutnya membuktikan bahwa pengguna internet yang dinilai dari segi usia didominasi oleh usia remaja yakni umur 20-24 Tahun. Remaja pada usia inilah yang saat ini dikenal dengan generasi digital native atau generasi $\mathrm{Z}$ yang menurut William J. Schroer di socialmarketing.com merupakan generasi yang lahir tahun 1995-2012.

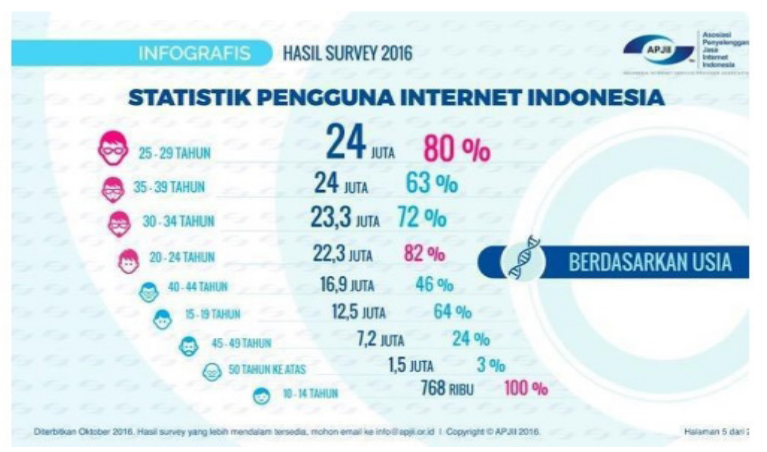

Gambar 2. Survey Warganet Berdasarkan Usia Tahun 2016

Generasi digital native inilah yang rentan terhasut digital hoax yang disebarkan melalui media sosial untuk bersikap radikal dan intoleran. Contohnya seperti yang dialami Muhammad Alfian Nauzi, seorang pemuda berusia 24 tahun yang diduga bergabung dengan ISIS (Islamic State of Iraq and Syria) di wilayah Suriah pada Maret lalu. Polisi menyatakan Alfian terpikat pada ISIS melalui pertemanan di Facebook dan perbincangan tertulis via telepon seluler (Tempo, 11 September 2016). Ketika era digital tiba, semua menjadi lebih mudah, murah, dan cepat. Media sosial telah mengubah cara orang berkomunikasi dan berinteraksi. Pemerintah tak mampu membendung kebebasan berpendapat dan berekspresi 
dari warganya. Keunggulan utama medsos dibandingkan dengan teknologi lainnya adalah hiperaktualitas dan interaktivitas. Teknologi informasi menjadi semakin terjangkau sehingga hampir semua orang memilikinya.

Dunia digital membuat semua media bisa disampaikan baik berupa suara, tulisan, simbol, tulisan, hingga video bisa diunggah untuk dibagikan kepada orang lain. Media ini dengan cepat dapat menyebarkan berita atau peristiwa untuk dikomentari, didiskusikan, ditindaklanjuti, atau disebarkan kembali melalui media lain seperti media cetak, radio, dan televisi. Media digital tidak mengenal batas wilayah, waktu, dan tempat. Fenomena ini sudah diramalkan oleh McLuhan pada 1962 melalui karyanya The Gutenberg Galaxy, bahwa suatu saat dunia ini akan mengalami ketergantungan terhadap teknologi dan menghubungkan dunia dan menjadi sebuah desa global (global village).

Tanpa disadari media digital telah mengubah cara orang berkomunikasi. Orang tak lagi berinteraksi sosial dengan orang lain secara langsung tetapi melalui media gawai. Komunikasi dilakukan secara cepat dan masal berdasarkan faktor kesamaan pandangan hidup, hobi, strata sosial, hingga agama. Hingga lahirlah interaksi digital yang terkotak-kotak. Mediabaruinisudahterlanjur dianggap sebagai media yang fleksibel dan bebas sensor. Masyarakat bebas menuliskan apa saja di dalamnya baik itu informasi valid yang bermanfaat maupun informasi hoax, unek-unek dan sumpah serapah. Sementara, regulasi yang ada belum mampu mengatasi persoalan-persoalan yang terjadi seiring dengan kemajuan teknologi komunikasi yang telah mengubah mindset manusia. Ini sejalan dengan pemikiran Merritt Row Smith mengenai determinasi teknologi, bahwa teknologi adalah kekuatan untuk mengatur manusia dan telah mengubah pola hidup manusia termasuk mobile technology seperti gawai.

Gawai saat ini sudah digunakan mulai dari anak kecil, anak muda hingga orangtua. Mirisnya orangtua tidak memberikan pengajaran terhadap yang muda dan yang muda juga tidak mau belajar terhadap yang tua, sehingga ibarat kumparan setan. Bahkan baru-baru ini banyak sekali memememe (parodi gambar) yang bertebaran di media sosial yang tidak dipahami artinya kemudian tanpa berpikir panjang langsung menshare informasi bahkan mereproduksi ulang informasi tanpa memikirkan dampak yang ditimbulkan setelahnya. Selain itu, banyak sekali ditemukan kasus-kasus yang tidak diinginkan turut terjadi dewasa ini, mulai dari cyberbullying, cybercrime, hingga kekerasan seksual di kalangan remaja Mereka beraktivitas di dunia digital dengan memprihatinkan, seperti contoh kasus ketika pemilihan kepala daerah di Jakarta yang sempat memperkeruh suasana di media social. Berangkat dari kecemasan dan keprihatin terhadap fenomena penyebaran hoax dan hate speech yang terjadi di media sosial. Prodi Ilmu Komunikasi UIN Sunan Kalijaga Yogyakarta yang berada dalam Fakultas Ilmu Sosial dan Humaniora merasa prihatin dengan fenomena ini dan kemudian menyelenggarakan kegiatan literasi digital untuk mahasiswa. Bentuk kegiatan ini berbeda dari yang sering diselenggarakan oleh lembaga lain yang lebih berfokus pada sosialisasi, ceramah, seminar dan pelatihan.

Prodi Ilmu Komunikasi UIN melalui ADUIN yang telah berjalan selama empat tahun ini berfokus pada literasi digital remaja yang tidak hanya berbentuk seminar, ceramah dan simulasi saja namun lebih dekat dengan dunia remaja yang cenderung menyukai dunia kompetisi, sehingga kegiatan ini berbentuk kompetisi ajang kreatifitas yang diperlombakan seperti Campaign Print, Campaign Digital Activation, Campaign TVC, Campaign melalui Film pendek. Semua kampanyeinidisebarkan melalui social media seperti youtube, IG, FB, Twitter dan Instant Messaging. Berdasarkan latarbelakang masalah di atas maka penelitian ini penting dilakukan untuk memetakan bagaimana generasi digital native melawan digital hoax melalui kompetisi kreatif?. Dengan tujuan agar remaja yang dilahirkan dengan kondisi dunia millennial dan tergolong sebagai digital native dapat menjadi cerdas 
dan kritis dalam menghadapi digital hoax. Penelitian ini akan bermanfaat secara teoritis dan praktis, harapannya penelitian ini dapat menjadi acuan bagi penelitian sejenis yang akan dilakukan selanjutnya dan dapat digunakan untuk pengembangan keilmuan terkait praktek literasi digital pada remaja dari kalangan mahasiswa. Sementara untuk masyarakat sebagai bahan referensi dan informasi serta menambah wawasan masyarakat khususnya mahasiswa terkait pengambilan sikap terhadap segala jenis informasi yang bersumber dari media social untuk menghindari pengkonsumsian dan penyebaran berita hoax atau berita bohong yang cenderung melanggar syariat agama.

Hoax bukan singkatan tetapi satu kata dalam bahasa inggris yang punya arti sendiri. Sedangkan definisi Hoax menurut wikipedia adalah "Sebuah pemberitaan palsu adalah usaha untuk menipu atau mengakali pembaca/pendengarnya untuk mempercayai sesuatu, padahal sang pencipta berita palsu tersebut tahu bahwa berita tersebut palsu. Hoax adalah berita bohong yang sengaja dibuat untuk menyamarkan kebenaran. Adapun hoax ini dapat dalam berbagai bentuk seperti:

1. Ide palsu (false idea),

2. Prinsip yang bertentangan (offence principle),

3. Manipulasi media (media manipulation),

4. Keseimbangan (balancing),

5. Objektifitas (objectivity),

6. Melawan netralitas moral (againts moral neutrality). (Raphael Cohen-Almagor, 2013).

Ide palsu (false idea), hanya dapat dibuktikan melalui hasil yang kongkret dan merusak. Prinsip yang bertentangan antara kebebasan dan toleransi tidak pernah dapat dipertemukan. Namun ide palsu yang menimbulkan pernyataan kebencian dan dapat merusak tatanan sosial sehingga, itu harus dikeluarkan dari kebebasan berpendapat. Prinsip yang bertentangan (offence principle), dapat dilihat dari kasus penistaan agama islam yang dilakukan oleh Basuki Tjahaja Purnama (Ahok). Manipulasi media (media manipulation), dapat dilihat sebagai hoax dari peliputannya. Di satu sisi, penistaan agama, media memberitakan dengan gencarnya sehingga Ahok diproses ke pengadilan. Di sisi lain, media juga memanipulasi pemberitaan bahwa Ahok tidak melakukan penistaan surat Al Maidah. Pemberitaan kedua belah pihak akan menimbulkansensasidalampemberitaannya. Hal ini juga akan menimbulkan hoax. Objektifitas (objectivity), memang menjadi senjata yang dapat mendukung hoax. Media mempergunakannya untuk membangun pencitraan medianya, agar dianggap prestise dan profesional sehingga apapun yang diberitakan dapat dipercaya oleh masa. Ketika media memberitakan sesuatu yang tidak benar dianggap sebagai kebenaran. Keseimbangan (balancing), menjadi prinsip dalam media masa. Ketidakseimbangan dalam pemberitaan media juga dapat menjadikannya hoax. Keseimbangan memerlukan unsur: akurasi, kebenaran penuh, keadilan dan keseimbangan berita. Kemudian yang terakhir Melawan Netralitas Moral (againts moral neutrality), media mencoba untuk tetap menjadi netral agar moral terjaga, akan tetapi demokrasi akan terancam. Pemberitaannya yang netral akan merusak prinsip demokrasi yang terkait dengan kebebasan media berpendapat.

Unsur hoax sama dengan unsur "penipuan", akan tetapi tidak ada yang perpindahan fisikyang terjadi. Penyebar hoax tidak harus memiliki tujuan yang pasti. Oleh karenanya, hoax menjadi perbuatan yang dapat dimasukkan kedalam ruang lingkup hukum pidana. Perbuatannya menyebarkan isu kebohongan yang mempengaruhi pikiran individu yang terkumpul menjadi pikiran masif. Ini sebenarnya ada "rantaian" kebohongan yang bersambung dari individu ke individu lainnya. Adapun hoax dapat berkembang karena kesalahan individu yang tidak meneliti informasi yang beredar. Oleh karenanya dalam UU ITE, individu yang meneruskan hoax kepada individu lainnya juga dianggap melakukan penyebaran informasi palsu. 
Kesalahan dalam observasi atau membuat penilaian, rumor dan urban legend tidak termasuk hoax. Hoax sengaja dibuat untuk menipu pembaca atau pendengarnya untuk mempercayai sesuatu dan menggiring opini mereka agar mengikuti kemauan pembuat hoax. Penyebaran hoax menggunakan pendekatan social engineering yaitu manipulasi psikologis dari seseorang dalam melakukan aksi atau menguak suatu informasi rahasia. Social engineering umumnya dilakukan melalui telepon atau internet dan yang paling mudah dilakukan melalui media sosial. Mekanisme yang dipakai seperti penggunaan judul atau foto bombastis, penggunaan akunakun samaran dengan foto perempuan cantik atau pria dengan profil meyakinkan di sosial media mengakibatkan orang mudah percaya terhadap akun tersebut dan percaya akan berita yang disebarkannya. Lebih dari ketrampilan teknis, penyebar hoax memperhitungkan aspek psikologis dan emosional. Hoax sangat jauh dari etika berkomunikasi sesame manusia. Dalam agama Islam sendiri etika berkomunikasi telah ada di kitab suci Al-Qur'an surat AlHujurat ayat 6.

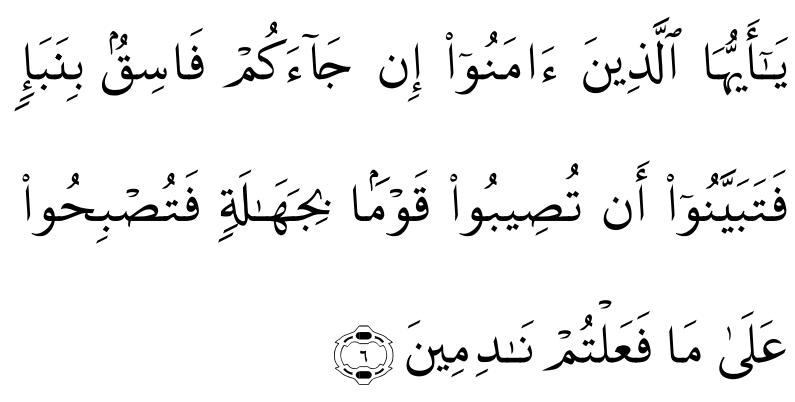

Artinya: "Hai orang-orang yang beriman, jika datang kepadamu orang fasik membawa sesuatu berita, maka periksalah dengan teliti agar kamu tidak menimpakan sesuatu kaum dengan perkara yang tidak diingini - dengan sebab kejahilan kamu (mengenainya) sehingga menjadikan kamu menyesali apa yang kamu telah lakukan".

Di dalam ayat tersebut kita diperintahkan untuk memeriksa kembali kebenaran sebuah berita dengan kata "Tabayyun" yang secara bahasa memiliki arti mencari kejelasan tentang sesuatu berita hingga jelas benar keadaanya. Sifat "Kebenaran" dan "Kebatilan" pada dasarnya adalah seperti air dan minyak. Keduanya berbeda dan tak bisa bercampur. hoax dapat mengaburkan kebenaran dan kebatilan yang akan membawa manusia pada kerusakan besar. Hoax mendapatkan momentum besar di era digital ini (Digital Age), di mana "kecepatan" menjadi yang utama, informasi menjadi mudah dibagikan tanpa melalui proses verifikasi, sehingga siapa saja, di mana saja, dan kapan saja bisa memproduksi, reproduksi dan mengkonsumsi konten hoax semudah menggerakkan ujung jarinya di gadget. Maka literasi digital menjadi salah satu upaya untuk melawan keganasan pengaruh negative informasi hoax dalam masyarakat.

Istilah literasi digital mulai popular sekitar tahun 2005 (Davis \& Shaw, 2011) Literasi digital bermakna kemampuan untul berhubungan dengan informasi hipertekstual dalam arti bacaan tak berurut berbantuan komputer. Istilah literasi digital pernah digunakan tahun 1980an, (Davis \& Shaw, 2011), secara umum bermakna kemampuan untuk berhubungan dengan informasi hipertekstual dalam arti membaca non-sekuensial atau nonurutan berbantuan komputer (Bawden, 2001). Gilster (2007) kemudian memperluas konsep literasi digital sebagai kemampuan memahami dan menggunakan informasi dari berbagai sumber digital, dengan kata lain kemampuan untuk membaca, menulis dan berhubungan dengan informasi dengan menggunakan teknologi dan format yang ada pada masanya. Penulis lain menggunakan istilah literasi digital untuk menunjukkan konsep yang luas yang menautkan bersama-sama berbagai literasi yang relevan serta literasi berbasis kompetensi dan ketrampilan teknologi komunikasi, namun menekankan pada kemampuan evaluasi informasi yang lebih "lunak" dan perangkaian pengetahuan bersama-sama pemahaman dan sikap (Bawden, 2008; Martin, 2006, 2008). IFLA ALP Workshop (2006) menyebutkan bagian dari literasi informasi adalah literasi 
digital, didefinisikan sebagai kemampuan memahami dan menggunakan informasi dalam berbagai format dari sejumlah besar sumber daya tatkala sumber daya tersebut disajikan melalui komputer. Sesusia perkembangan Internet, maka pemakai tidak tahu atau tidak mempedulikan dari mana asalnya informasi, yang penting ialah dapat mengaksesnya.

Generasi yang lahir di era 1980-an hingga 2000-an adalah generasi yang tumbuh di era digital. Mereka ada di dunia ketika internet mulai merajalela. Marc Prensky menyebut mereka sebagai generasi digital native. Berdasarkan hasil survey APJII 2016 mengungkap bahwa penetrasi pengguna internet di Indonesia berdasarkan pekerjaan di ungguli oleh mahasiswa dengan persentase $89,7 \%$. Mahasiswa menduduki peringkat pertama pengguna internet yang paling aktif.

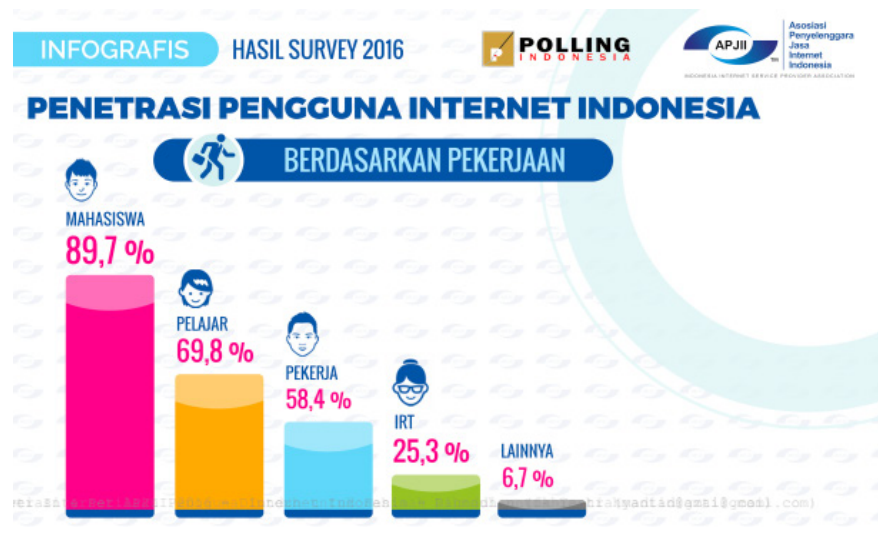

Gambar 3. Survey berdasarkan pekerjaan (APJII, 2016)

Petro Blos (Sarlito, 2003) mencoba menerangkan tahap-tahap perkembangan dalam kurun usia remaja, Blos yang penganut aliran psikoanalisis berpendapat bahwa perkembangan pada hakikatnya adalah usaha peyesuaian diri (coping), yaitu untuk secara aktif mengatasi stress dan mencari jalan keluar baru dari berbagai masalah. Dalam proses penyesuaian diri menuju kedewasaan, ada tiga tahap perkembangan remaja, yaitu sebagai berikut :

1. Remaja awal (early adolescence). Pada tahap ini remaja masih terheran-heran akan perubahan-perubahan yang terjadi pada tubuhnya sendiri dan dorongan-dorongan yang menyertai perubahan-perubahan itu. Remaja dapat mengembangkan pikiran-pikiran yang baru, cepat teratarik pada lawan jenis, dan mudah merasa terangsang secara erotis.

2. Remaja madya (middle adolescence). Pada tahap ini remaja sangat membutuhkan teman-teman. Ia merasa senang bila memiliki banyak teman yang menyukainya. Ada kecenderungan "narcistic", yaitu mencintai dirinya sendiri, serta menyukai teman-temannya yang memiliki sifat sama seperti diriya.

3. Remaja akhir (late adolescence). Pada tahap ini dapat disebut masa konsolidasi menuju periode masa dewasa dengan mencapai 5 hal, yaitu:

a. Minat yang makin mantap terhadap fungsi-fungsi intelek.

b. Egonya mencari kesempatan untuk bersatu dengan orang-orang lain dan dalam pengalaman-pengalaman baru.

c. Terbentuknya identitas seksual yang tidak akan berubah lagi.

d. Egoisentrisme (terlalu memusatkan perhatian pada diri sendiri) diganti dengan keseimbangan antara kepentingan diri sendiri dengan orang lain.

e. Tumbuh "dinding" yang memisahkan diri pribadinya (private self) dan masyarakat umum (the public). (Sarlito. 2003).

Mahasiswa dikategorikan remaja akhir dan dewasa awal, pada masa itu umumnya berada pada masa transisi dan pengguna aktif media digital. Tidak dapat dinafikkan bahwa media digital lebih erat berhubungan dengan remaja daripada orangtua dan gurunya. Dalam kondisi seperti ini, melarang mereka untuk tidak berhubungan dengan media digital bukanlah pilihan tepat karena arus digitalisasi sudah tidak terbendungkan lagi karena dapat diakses kapan saja dan dimana saja. Remaja merupakan kelompok budaya 
yang berbeda dan signifikan, sebagai sebuah segmen pasar, sebuah subkultur dan yang memimpin jalan dalam penggunaan media digital. Remaja adalah titik dimana mereka berusaha untuk membangun identitas, untuk membentuk kelompok sosial, dan untuk menegosiasikan makna budaya yang mereka miliki. Dan di antara semuanya, media menjadi bagian pusatnya (Osgerby, 2004). Remaja menjadi objek komodifikasi yang potensial untuk produser media yang memiliki tujuan pemasaran transgenerasi.

Dalam literasi digital setidaknya terdapat beberapa tahapan dalam pelaksanaannya untuk remaja, (Jenkins, 2009) :

\section{Literasi budaya media cetak.}

Di sini remaja dituntut untuk memiliki kemampuan untuk menulis dan membaca di media cetak. Menulis blog, jurnal, mengungkapkan opini dan membalas komentar orang lain menjadi cara awal untuk mengasah kemampuan di print culture. Literasi media konvensional ini menjadi "indera penglihatan" bagi konsumsi media digital.

\section{Kemampuan meneliti.}

Kemampuan untuk dapat mengakses buku, artikel, menggabungkan dan menganalisis informasi, membedakan antara fakta dan opini, membangun argumen menjadi kemampuan kedua yang harus dimiliki. Dunia disajikan kepada kita dalam bahasa, simbol yang tidak hanya memiliki pemaknaan tingkat pertama. Kemampuan untuk melakukan penelitian menjadikan remaja memiliki analytical competence, menjadikannya tidak hanya bisa membaca melainkan "membaca" sesuatu hal.

\section{Keahlian teknis.}

Mengikutsertakan keahlian digital media seperti log on, search, editing dan pengetahuan teknis yang berkaitan dengan pengoperasian media baru. Pengetahuan tentang teknis tidak boleh dianggap sepele. Perkembangan teknologi yang semakin cepat mengarah kepada tingkat adaptasi kemampuan operasionalisasi media yang cepat juga. Penguasaan yang tinggi terhadap kemampuan teknis ini harusnya juga dilengkapi dengan pengetahuan tentang terms of service yang biasanya dimiliki media baru, seperti Facebook.

\section{Studi media.}

Pengetahuan terhadap bagaimana media beroperasi, ekonomi media, politik, serta seluruh aspek yang menyertainya juga menjadi hal penting bagi literasi remaja. Kita disuguhi media yang telah dikonstruksi oleh komunikatornya. Dunia dihadapkan kepada kita dalam persepsi yang telah disusun sesuai kepentingan pemilik modal. Kemampuan untuk bisa memposisikan diri sebagai produsen pesan, membuat remaja lebih waspada terhadap media yang mereka konsumsi.

Keempat tahapan tersebut di atas menjadi dasar literasi yang harus dikuasai oleh remaja ketika mereka berinteraksi dan berkomunikasi dengan media digital.

McQuail (2008) mengatakan bahwa media digital atau sering di sebut media baru adalah tempat di mana seluruh pesan komunikasi terdesentralisasi;distribusi pesan lewat satelite meningkatkan penggunaan jaringan kabel dan komputer, keterlibatan audiens dalam proses komunikasi yang semakin meningkat. Ron Rice juga mendefinisikan media baru sebagai media teknologi komunikasi yang melibatkan komputer di dalamnya (baik mainframe, PC maupun Notebook) yang memfasilitasi penggunanya untuk berinteraksi antar sesama pengguna ataupun dengan informasi yang diinginkan. Media baru dapat memberikan pengaruh positif dan negatif. Berbagai macam Informasi dari media baru sangat mudah, cepat, ekonomis dan dapat di akses di mana pun. Media ini dapat membawa pengaruh yang signifikan dalam kehidupan masyarakat. Jika masyarakat tidak memiliki kapasitas keilmuan dan kemampuan literasi media yang baik, maka pengaruh negative media akan sangat mudah masuk dan menerpanya. Disinilah salah satu poin penting pelaksanaan literasi media digital untuk masyarakat khususnya mahasiswa yang menduduki peringkat pertama pengakses aktif internet.

\section{METODE}


Penelitian ini menggunakan pendekatan deskriptif kualitatif yang menurut Denzin dan Lincoln (2009:2) penelitian kualitatif memiliki ciri bahwa data yang disajikan dalam bentuk deskripsi yang berupa teks naratif, kata-kata, ungkapan, pendapat, gagasan yang dikumpulkan oleh peneliti dari beberapa sumber sesuai dengan teknik atau cara pengumpulan data. Kemudian data di kelompokkan berdasarkan kebutuhan dengan pendekatan interpretatif terhadap subjek selanjutnya dianalisis. Penelitian ini tidak mengutamakan besarnya populasi atau sampling, jika data yang terkumpul sudah cukup mendalam dan bisa menjelaskan fenomena yang diteliti maka tidak perlu mencari sampling lainnya (Kriyantono, 2009). Objek penelitian ini adalah kampanye literasi digital sementara subyek penelitian ini adalah mahasiswa sebagai digital native. Sumber data primernya berasal dari pengelola, panitia dan peserta ADUIN Fest 2017 "Nyepik Becik" (Pikirkan Apa yang Kamu Katakan)". Sementara data sekundernya didapatkan melalui observasi dan wawancara mendalam. Wawancara mendalam dapat dilakukan pada waktu dan kondisi konteks yang dianggap paling tepat guna mendapatkan data yang rinci, jujur dan mendalam (Sutopo, 2002). Teknik analisis datanya menggunakan analisis interaktif, kemudian untuk memvalidasi data menggunakan trianggulasi sumber.

\section{HASIL DAN PEMBAHASAN}

\section{Kompetisi Kreatif Mahasiswa Sebagai Wujud Literasi Media Partisipatif}

Berdasarkan temuan lapangan mengungkapkan bahwa kompetisi kreatif yang digagas oleh ADUIN merupakan wujud dari literasi media partisipatif. ADUIN adalah sebuah ajang kompetisi tahunan yang diselenggarakan oleh Program Studi Ilmu Komunikasi konsentrasi Advertising UIN Sunan Kalijaga Yogyakarta. Kegiatan ini merupakan kegiatan yang sudah berlangsung selama 4 tahun terakhir, tahun 2017 ini tema yang diusung adalah "Nyepik Becik-Pikirkan Apa yang Kamu Katakan”. Menurut panitia pelaksana, tema ini diambil dari bahasa Jawa. Kata "nyepik" memiliki makna "berbicara". Sedangkan "becik" memiliki makna "baik" atau "bijak". Sehingga "nyepik becik"diartikan sebagai "berbicara dengan baik". Untuk dapat berbicara dengan baik maka yang harus dilakukan adalah dengan memikirkan apa yang hendak dikatakan. Tema tersebut adalah sebagai respon munculnya pemikiran bahwa pesatnya perkembangan teknologi komunikasi telah membuka ruang sebebasbebasnya bagi siapapun untuk berpendapat melalui berbagai media komunikasi khususnya media sosial. Kenyataan tersebut telah menimbulkan berbagai permasalahan dalam kehidupan masyarakat Indonesia, seperti maraknya penyebaran hoax, cyberbullying dan hatespeech. Ini merupakan persoalan yang sangat serius karena jika tidak segera diperangi dan ditindak lanjuti, maka dapat mengancam keselamatan dan ketahanan nasional bangsa. Di masa yang akan datang ancaman, tantangan dan hambatan bangsa Indonesia akan semakin kompleks apalagi perkembangan teknologi komunikasi semakin canggih, sehingga persiapanamunisi untuk memerangi dampak buruk dari internet dapat di tanggulangi sejak dini. Sudah banyak kasus sensitive yang terjadi terkait penggunaan internet mulai dari penyebaran hoax, perundungan dan ujaran kebencian yang dapat memicu lahirnya konflik-konflik yang penuh dengan kepentingan tertentu.

Zaman sekarang dengan kemajuan teknologi yang sangat pesat, beritaberita hoaks dengan mudah menyebar ke masyarakat. Berita dan informasi hoax menjadi semakin subur dengan tersedianya berbagai aplikasi jejaring sosial dengan ketidakakuratan informasi dan ada pula yang sengaja menyesatkan. Bermunculannya berita dan informasi hoaks itu, lanjut dia, berpotensi memecah belah antarkomponen bangsa sehingga keberadaan media "online" berperan menjadi penangkalnya. Keberadaan mahasiswa sebagai agent perubahan yang nantinya akan memegang kendali Negara ini haruslah memiliki kreatifitas untuk meningkatkan kemampuan 
dan kompetensi melawan digital hoax yang bersebaran tanpa kendali di media digital yang saat ini sangat akrab dalam kehidupan masyarakat utamanya kaum remaja. Upaya yang dilakukan pengelola program studi Ilmu Komunikasi melalui acara tahunan yang diberi nama ADUIN ini menjadi wadah untuk mengasah kreatifitas mahasiswa dalam menggunakan media sosial. Beberapa tahun lalu tema yang diangkat oleh ADUIN adalah The Journey of Creative (2014), Creamorphosa (2015), Real-tionship (Real Action on Relationship) (2016), dan Nyepik Becik (Pikirkan Apa yang Kamu Katakan) (2017). Semua kegiatan yang di gagas oleh ADUIN ini menuntut mahasiswa yang menjadi peserta perlombaan untukmengedepankan kreatifitas dalam menggunakan di era perkembangan teknologi digital pada saat ini melalui penciptaan karya-karya yang baik dan bermanfaat. Pernyataan ini juga di dukung oleh Handoko Herdroyono salah satu pembicara talkshow ADUIN 2017 yaitu,"berinovasilah dalam menguangkan ide-ide kreatif dalam persaingan di dunia bisnis untuk mengemas iklan dengan pesan yang menarik baik content- meaningmonetizing yakni good communication, kunci sebuah karya adalah adjusment, dan passion yang kalian punya jika tanpa berkarya itu percuma".

Tema yang digunakan oleh ADUIN tahun 2017 ini menjadi bagian dari kampanye literasi digital bagi masyarakat khususnya mahasiswa Indonesia. Melalui tema tersebut, diharapkan generasi muda Indonesia mampu mengedukasi dirinya sendiri maupun orang lain untuk peduli dan berperan aktif melawan bahaya pengaruh negative dari cyberbullying, hoax dan hatespeech yang marak terjadi di media digital utamanya di media sosial. Pendekatan yang dilakukan adalah melalui pendekatan partisipatif dengan langsung mempraktekkannya melalui penciptaan karya-karya kreatif yang nantinya akan dikompetisikan. Adapun data yang didapatkan menerangkan bahwa terdapat beberapa rangkaian kegiatan yang telah dilaksanakan oleh panitia ADUIN yaitu, kegiatan pertama adalah kompetisi periklanan. Dalam kompetisi kreatif ini, terdapat 3 kategori dalam kompetisi periklanan.

1. PrintAd. Dalam kategori kompetisi ini peserta diminta untuk mengemas ide kreatif dalam bentuk iklan cetak.

2. TV Commercial. Disini peserta diminta untuk membuat iklanlayanan masyarakat dalam format $T V$ commercial.

3. Digital Activation. Peserta diminta untuk membuat konsep ide kreatif iklan memanfaatkan media digital.

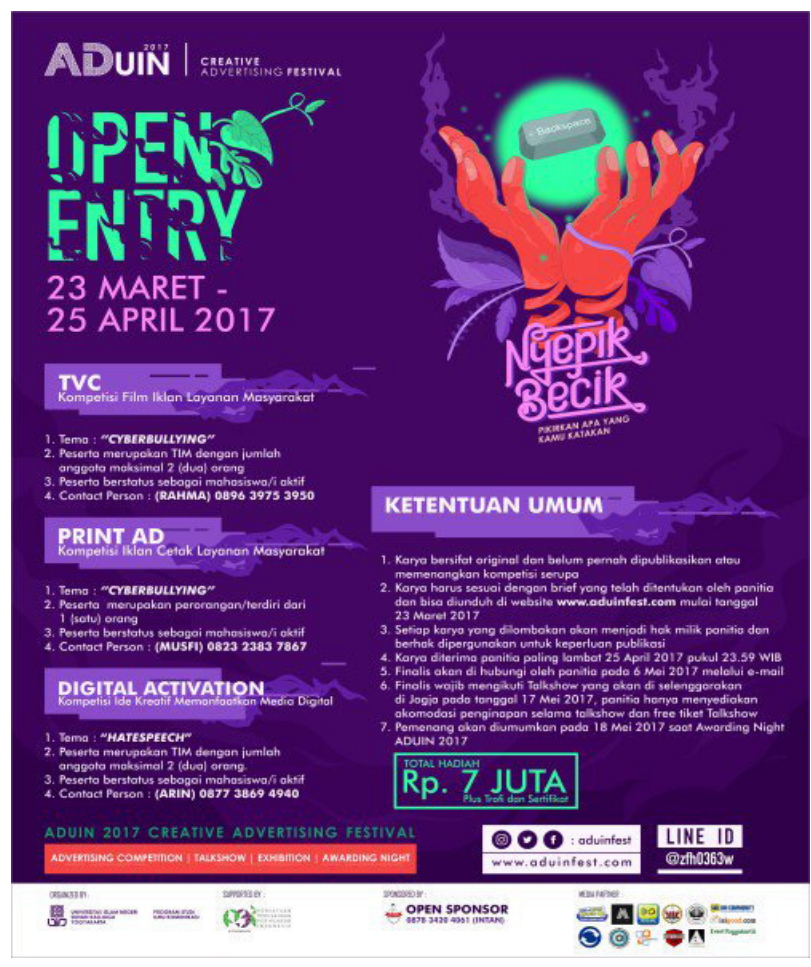

Gambar 4. Poster Open Brief Dan Open Entry (ADUIN, 2017)

Hal yang telah dilakukan dan dilaksanakan oleh pihak ADUIN di atas masuk dalam kategori tahapan dalam literasi digital versi Henry Jenkins yaitu tahapan literasi media cetak, keahlian teknis dan studi media. Pada tahapan literasi media cetak, yaitu mahasiswa peserta ADUIN mampu menulis dan mengungkaapkan opini pada print culture, literasi media konvensional ini menjadi "indera penglihatan" bagi konsumsi media digital. Kemudian pada keahlian teknis, mahasiswa memiliki keahlian digital media seperti $\log$ on, search, editing dan pengetahuan teknis yang berkaitan dengan 
pengoperasian media digital. Disini peserta kegiatan harus mengunduhinformasi melalui www.aduinfest.com disinilah alat bantu untuk menerjemahkan pengertian hoax itu apa? Penanggulannya harus bagaimana dan harus bisa memecahkan brief yang ada sesuai dengan karakter mereka sebagai mahasiswa dan menghasilkan campaign anti-hoax di social media itu seperti apa?. Kemudian mereka membuat start up (jenis program kegiatan) yang bisa dikembangkan. Harapannya program aplikasi yang mereka kreasikan dapat diaplikasikan, dieksekusi dan disebarkan kepada teman-temannya (digital activation). Setelah itu tahapan studi studi media, ini merupakan tuntutan kemampuan mahasiswa untuk bisa memposisikan diri sebagai produsen pesan, ini dapat membuat mereka lebih waspada terhadap media yang mereka konsumsi. Anak-anak muda (mahasiswa) lebih peka terhadap bahaya hoax, cyberbullying dan hatespeech sehingga mereka tidak hanya sekedar mengkritisi tetapi juga memberikan solusi dengan memberikan Campaign Print, Campaign Digital Activation, Campaign TVC, Campaign melalui Film pendek. Semua kampanye ini di sebarkan melalui social media seperti youtube, IG, FB, Twitter dan Instant Messaging.

Dalam setiap kategori yang dikompetisikan peserta diminta untuk mengkampanyekan aksi peduli nyata terhadap bahaya hoax, cyberbullying dan hatespeech melalui penciptaan iklan layanan masyarakat (ILM). Berdasarkan keterangan dari narasumber, peserta dapat memperoleh informasi lebih lanjut mengenai brief dan alur pendaftaran untuk pengiriman karya peserta dengan mengunduh pada situs website www.aduinfest.com. Alamat website ini selalu digunakan untuk memberikan informasi-informasi terkini perkembangan penyelenggaraan ADUIN. Ketika itu jeda waktu ketika kegiatan akan dilaksanakan berkisar satu bulan sehingga para calon peserta dapat mempersiapkan karya terbaiknya untuk diperlombakan. Harapannya mereka benar-benar dapat memahami dan meresapi akan ancaman bahaya penyebaran hoax, cyberbullying dan hatespeech melalui penciptaan karya kreatif mereka yang kemudian akan dikampanyekan melalui media social mereka dan di publish secara massal di halaman web ADUIN.

Para mahasiswa yang menjadi calon peserta dapat melakukan pengiriman karya mulai tanggal 23 Maret 2017 sampai 25 April 2017. Kompetisi kreatif ini terbuka untuk umum, dan berlaku bagi seluruh mahasiswa/i Si di seluruh Indonesia. Untuk menambah semangat para calon peserta, panitia juga menyediakan dana pembinaan bagi peserta yang berhasil menang kompetisi ini dengan total hadiah bagi pemenang mencapai 7 juta. Selain hadiah dalam bentukuang pembinaan, terdapat pula Trophy AdUin dan piagam penghargaan yang diberikan bagi masingmasing pemenang yang terpilih. Perlombaan ini merupakan ragam bentuk kegiatan dalam melaksanakan dan mengkampanyekan pentingnya literasi digital dalam masyarakat khususnya bagi mahasiswa Indonesia yang merupakan agent of change dan calon pemimpin bangsa ini. Menurut data yang berhasil dihimpun, kompetisi kreatif untuk mahasiswa yang concern pada studi media digital dan periklanan ini diikuti oleh 133 peserta yang terdiri dari 106 karya Print Ad, 18 karya Digital Activation dan 9 karya TVC.

Ketua pelaksana ADUIN mengungkapkan dari ketiga kompetisi iklan ini yang menarik dari kompetisi yang diadakan Aduin di tahun sebelumnya yaitu kategori Digital Activation, di mana kategori ini memiliki perbedaan ketertarikan peserta untuk mengikuti lomba. Bahwa kategori ini paling dekat diera digital saat ini dalam menyampaikan ide-ide kreatif tak hanya melalui media sosial saja, tetapi juga dapat melalui sebuah iklan dengan intergrasikan sebuah poster dengan media digital, seperti penggunaan website, gadget maupun media sosial. Kemudian, karya-karya peserta yang lolos penjurian etika akan di pameran di Gallery selama dua hari pelaksana Aduin berlangsung. Gallery yang dibuka dalam lingkup Mini Stage merupakan rangkaian dari salah satu kegiatan Aduin, berupa tampilan karya-karya dari peserta yang mengikuti 
lomba yang lolos penjurian etika oleh juri. Mini Stage ini bertujuan untuk membagikan wawasan kepada khalayak yang berkunjung ke Gallery mengenai persoalan-persoalan Hoax, hatespeech dan cyberbullying. Dengan adanya kompetisi iklan ini harapannya dapat memberikan kontribusi positif dan wawasan terkait upaya pencegahan tindakan-tindakan cyberbullying dan hatespeech dengan mendorong mahasiswa menuangkan ide kreatifnya melalui sebuah karya berupa Iklan. Apalagi target utamanya adalah mahasiswa komunikasi yang memang seharusnyalah cerdas terhadap media, karena kelak akan berkarir di dunia media massa tentu punya kewajiban untuk meluruskan informasi yang palsu sehingga khalayak sebagai konsumen tidak ikut terjebak di dalamnya.

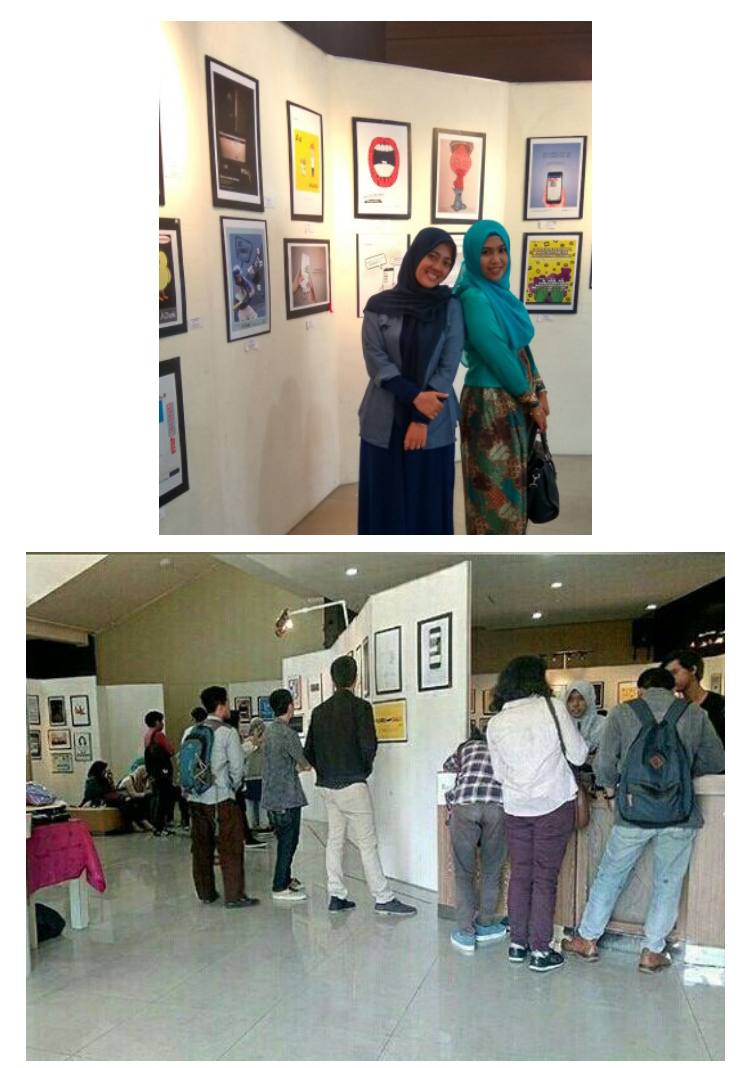

Gambar 5. Pameran karya-karya PrintAd Peserta (ADUIN, 2017)

Data penelitian lainnya menunjukkan bahwa bentuk-bentuk karya yang dikompetisikan dalam acara ini mendapatkan respon yang luar biasa dari para mahasiswa yang tidak hanya berasal dari Yogyakarta, namun juga berasal dari wilayah lainnya seperti Bali, Jakarta, Bandung, Surabaya, Malang dll. Promosi kegiatan dilakukan melalui road-show ke beberapa universitas yang ada di Jogja dan Luar Jogja seperti di UII, AKRB, AMIKOM, AKINDO, UPN, UMY, Atmajaya, Petra Surabaya, UPN Surabaya, UNDIP. Wilayah Jakarta dan wilayah lainnya disebarkan melalui Flyer kegiatan. Perbedaan jenis promosi ini terjadi akibat lemahnya dukungan anggaran promosi kegiatan sehingga hanya menggunakan jasa media cetak berupa flyer yang dikirimkan melalui layanan pos.

\section{Digital Native Melawan Digital Hoax}

Mahasiswa sekarang yang terlahir sebagai digital native merupakan generasi muda yang sedang berkembang dan akan matang pada saatnya. Mereka adalah calon generasi pemimpin bangsa yang akan membawa negara ke arah perubahan yang lebih baik. Salah satu perubahan yang bisa dilakukan mahasiswa adalah melakukan partisipasi aktif dalam memerangi kedzaliman dan ketidakadilan di muka bumi. Mahasiswa bisa berperang melawan hoax yang disebar melalui dunia digital maupun dunia nyata yang semakin lama semakin deras tak terkontrol. Ini merupakan masalah kita bersama selaku warga Negara Indonesia. Hoax mendapatkan kesempatan dan momentum besar di era perkembangan teknologi digital saat ini (Digital Age). Di tengah arus informasi di mana "kecepatan" menjadi yang utama, informasi menjadi mudah dibagikan tanpa melalui proses verifikasi, sehingga siapa saja, di mana saja, dan kapan saja bisa memproduksi, reproduksi dan mengkonsumsi konten hoax semudah menggerakkan ujung jarinya di gadget. Jika dahulu ada peribahasa "mulutmu harimaumu", di era digital seperti sekarang ini peribahasa tersebut mungkin bermetamorfosa menjadi "jarimu harimaumu". Ini lah mengapa literasi digital semakin menjadi sangat penting untuk memerangi digital hoax.

Berdasarkan data penelitian, ADUIN 
tidak hanya melakukan kompetisi kreatif dalam mengkampanyekan literasi digital namun juga melakukan kampannye melalui talkshow kreatif kemudian di ikuti awarding night bagi peserta yang berhasil memenangkan kompetisi karya anti hoax, hatespeech dan cyberbullying. Disinilah letak perbedaan bentuk kegiatan literasi digital yang ditawakan oleh ADUIN kepada masyarakat, yaitu bentuk kegiatannya lebih kearah kolaboratif dan partisipatif.

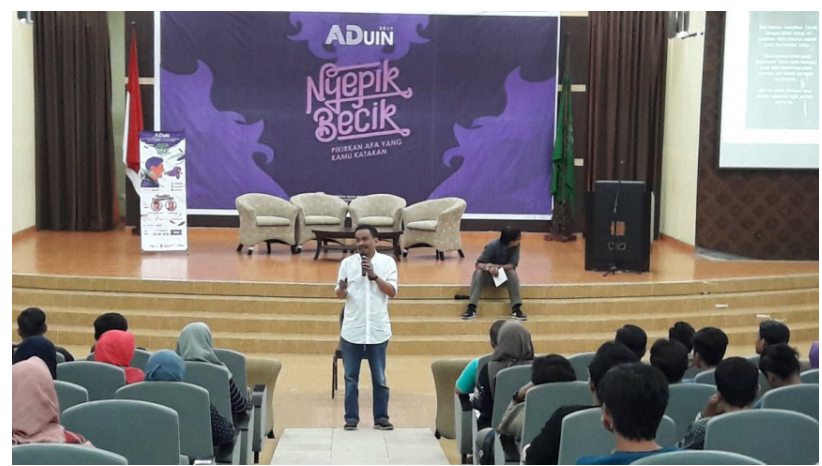

Gambar 6. Talkshow kreatif (ADUIN, 2017)

Kegiatan talkshow dihadiri para pakar dalam dunia periklanan Indonesia yang telah terlaksana pada 17 Mei 2017. Talkshow ini Mengusung tema "Creative Talkshow", peserta talkshow akan mendapatkan pengetahuan baru mengenai bagaimana teknik merancang pesan dengan baik dan efektif, sehingga membuat target audience terkesan. Ini juga merupakan strategi untuk melawan hoax, ujaran kebencian dan perundungan yang kerap terjadi. Iklan juga merupakan produkyang akan bersinggungan langsung dengan masyarakat, sehingga para kreator iklan juga seharusnya sadar dan ikut peduli dalam menciptakan pesanpesan yang ramah, baik dan efektif. Generasi muda haruslah memiliki kecerdasan dalam bermedia agar mendapatkan manfaat yang positif dari media karena media dan teknologi itu ibarat dua mata pedang disatu sisi memiliki dampak positif di sisi lain juga memiliki dampak negative.

Menurut pengurus dan panitia AdUin, Kegiatan "Creative Talkshow" ini lebih terbuka untuk umum, sehingga dapat diakses banyak stakeholders. Siapapun dapat mengikuti kegiatan ini dengan melakukan pendaftaran melalui situs resmi AdUin. Untuk mengapresiasi karya-karya kreatif, AdUin juga menggandeng berbagai komunitas desain, fotografi, advertising dan masih banyak lagi komunitas lain dalam kegiatan Gallery Ad AdUin. Dengan konsep pameran karya, dalam Gallery $A d$ pengunjung akan disuguhkan karya-karya kreatif dari berbagai komunitas. Tak hanya pameran karya dari komunitas, pengunjung juga dapat melihat berbagai macam karya para peserta dari 3 kategori kompetisi AdUin. Kemeriahan Awarding Night akan menjadi penutup dari rangkaian kegiatan AdUin 2017. Awarding Night juga merupakan acara yang terbuka untuk umum yang akan dilaksanakan tanggal 18 Mei 2017.
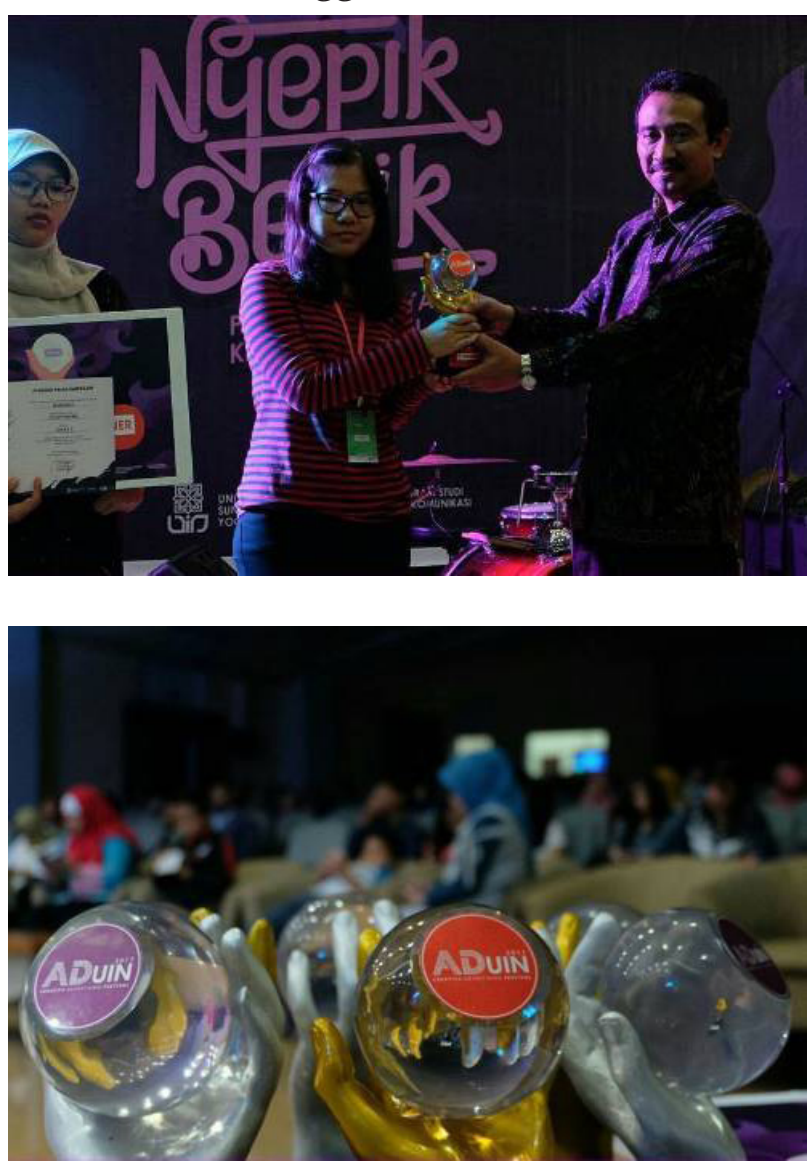

Gambar 7. Awarding Night (AdUin, 2017)

Sebagai puncak dari event AdUin, kegiatan penutup ini dikonsep dengan sangat meriah. Dalam Awarding Night ini panitia mengumumkan pemenang dari masingmasing kategori yang dikompetisikan dalam AdUin 2017. Terdapat pula guess yang 
akan memberikan hiburan meriah dalam penutupan rangkaian acara AdUin 2017. Kompetisi kreatif yang telah dilaksanakan oleh AdUin ini setidaknya menambah ragam bentuk dari penyelenggaraan literasi digital partisipatif di dalam masyarakat. Adapun beberapa output dari kegiatan literasi digital ini adalah mahasiswa lebih peka dan sensitive terhadap mana informasi hoax dan mana informasi yang terpercaya melalui pelacakan sumber yang jelas, kemudian mereka tidak memproduksi ataupun mereproduksi pesan-pesan yang salah dan mahasiswa dapat menghasilkan program startup (aplikasi internet) yang dapat mendeteksi dan mencegah hoax kemudian jika terdapat indikasi hoax dapat segera melaporkannya kepada pihak yang berwenang.

Sebagai agen perubahan dan calon pemimpin bangsa yang menguasai teknologi informasi, mahasiswa Indonesia harus mampu memilah dan memilih informasi yang akurat sehingga tidak terjebak dalam hasutan hoax (informasi palsu). Apalagi sebagai mahasiswa ilmu komunikasi di UIN ini, memang seharusnyalah cerdas terhadap media, karena kelak akan berkarir di dunia media massa tentu punya kewajiban untuk meluruskan informasi yang palsu sehingga khalayak tidak ikut terjebak di dalamnya. saat ini media, terutama media sosial, dibanjiri dengan hoax yang kadang sulit dibedakan dengan informasi faktual. Tujuan penyebarannya untuk membuat masyarakat merasa tidak aman, tidak nyaman, dan kebingungan. Akhirnya, masyarakat yang sedang bingung ini akan mengambil keputusan yang lemah, tidak meyakinkan, dan bahkan salah langkah. Pendiri Indonesian Hoax Buster (IHB) mengatakan, jenis hoax yang diterima masyarakat Indonesia paling banyak berkaitan dengan isu sosial politik. Antara lain pemilihan kepala daerah atau pemerintahan (91,8\%), isu SARA $(88,6 \%)$, dan isu kesehatan $(41,2 \%)$. Adapun media yang paling banyak dijadikan sebagai tempat penyebaran informasi atau berita palsu ini berupa media sosial seperti Twitter, Facebook, dan Instagram (92,4\%), Aplikasi Chatting seperti Whatsapp, Line, dan Blackberry
Messenger (62,8\%), dan situs (web) sebesar 34,9\%. (Pratiwi, 2017). Berdasar hasil penelitian didapatkan hasil bahwa penyebar hoax umumnya menolak realitas dan menolak kebenaran yang ada di masyarakat, sehingga dirinya lantas membentengi diri dan mengupayakan agar masyarakat bisa meyakini apa yang dia yakini, walau itu tidak sejalan dengan realitas yang ada.

\section{SIMPULAN}

Mahasiswa merupakan agent of change dan calon penerus bangsa ini, sehingga harus diberikan bekal dan pemahaman yang baik terkait dunia digital. Pengemasan kegiatan berupa kompetisi kreatif/ perlombaan, karena anak muda itu senang berkompetisi. Hoax baik dalam bentuk digital hoax maupun tidak haruslah dihindari dan diwaspadai. karena hoax itu penyakit yang menyebar dan menular untuk menipu orang lain. Sehingga generasi muda haruslah memiliki kecerdasan dalam bermedia agar mendapatkan manfaat yang positif dari media karena media dan teknologi itu ibarat dua mata pedang, disatu sisi memiliki dampak positif di sisi lain juga memiliki dampak negative. Peneliti merekomendasikan agar diharapkan melalui kegiatan ini tidak hanya dilaksanakan di Jogja saja tetapi juga berkembang dikota-kota besar lainnya. Seperti di Jakarta, Surabaya, Semarang Bandung dll. Asumsinya di kota besar inilah 6o \% produksi Hoax merajalela. Rekomendasi selanjutnya adalah agar pihak pemerintah semakin cepat tanggap atas dinamika yang terjadi dalam perkembangan pesat teknologi komunikasi yang telah merubah mindset masyarakat sehingga membutuhkan regulasi agar ada payung hukum yang jelas terkait fenomena hoax, hate speech dan cyber bullying. Ketika regulasi telah kuat maka dampak negative media digital dapat diminimalisir. Marilah kita menanamkan semboyan dalam berinteraksi di internet yaitu, berfikir sebelum kita bertindak "Think Before You Act" dan "Turn Back Hoax". 


\section{DAFTAR PUSTAKA}

Bawden, D. (2001). Information and digital literacy: a review of concepts. Journal of Documentation, 57(2),218-259

Bawden, D. (2008). Origins and concepts of digital literacy. Dalam C. Lankshear\&M. Knobel (eds). Digital literacies: concepts, policies, and paradoxes. Pp:1532. New Yok: Peter Lang

Davis, Charles H.; Shaw,Debora (eds). (2011). Introduction to information science and technology. Medford,NJ: Information Today

Gilster, P. (1997). Digital literacy. New York;Wiley

IFLAALPWoorkshopon Information Literacy and IT, Auckland,New Zealand. (2006). The basic information literacy skills.

Jenkins, Henry. 2009. Confronting The Challenges of Participatory Culture: Media Education for the 21st Century. Illinois: MacArthur Foundation.

Kriyantono, R. (2009). Teknik Praktis Riset Komunikasi, Jakarta: Kencana Media Group

Lincoln, \& Denzin. (2009). Handbook of Qualitatif Research. Pustaka Pelajar: Yogyakarta.

Martin, A. (2006). Literacies for tge digital age. Dalam A.Martin\&D.Madigan(eds). Digital literacies forlearning. London:Facet.

Martin,A. (2008). Digital literacy and the"digital society:. Dalam C. Lanskhear \& M.Konel(eds). Digital literacies: concepts, policies, and paradoxes. New York:Peter Lang

McQuail, Denis. (2008). McQuail's Mass Communication Theory. (5th edt). Sage publication.

Osgerby, Bill. (2004). Youth Media. London: Routledge
Raphael Cohen-Almagor (2013). Freedom of Expression V. Social Responsibility: Holocaust Denial in Canada. Journal of Mass Media Ethics 28 (1):42 - 56.

Sarwono, Sarlito. (2003). Psikologi Remaja. Jakarta: PT. Raja Grafindo Persada

Sutopo. (2002). Metodologi Penelitian Kualitatif. Surakarta: Sebelas Maret University Press

Pratiwi, Citra. 2017. Mahasiswa Harus Bisa Menolak Hoax. https://youngster.id/ news/mahasiswa-harus-bisa-menolakhoax. Diakses pada 29 Oktober 2017.

h t t p s : / / m a ja l a h . t e m p o.c o / site/2016/o9/o4/970/cover_2846, diakses 15 Agustus 2017

https://apjii.or.id/survei2o17/download/oP H753kUeXWi8QtsYV1cEOJGDg 4 BjR, diakses 26 Agustus 2017

http://alvara-strategic.com/generasi-z-anakkandung-internet, diakses 1 September 2017

https://id.wikipedia.org/wiki/Pemberitaan_ palsu/hoax, (diakses, 25 September 2017) 